areas where such committees have not been organized.

(3) These action committees give increased attention to providing train ing for field foresters and other woods workers in the evaluation of forest insect populations and the detection of incipient insect outbreaks.

(4) The regional action committees coordinate their activities with the objective of controlling insect depredations with minimum losses and at the lowest cost.

(5) The various state, provincial, and federal legislatures set up a revolving fund to be made available to the proper authorities for use in combatting outbreaks of forest pests and diseases when emergency action warrants, in order to prevent incipient outbreaks becoming epidemic."

\title{
REVIEWS
}

Reviews of books, reports, papers and other publications should be sent to J. Walter Giles, Book Review Co-ordinator, Department of Lands and Forests, 504 Wellington St. W. Toronto, Ontario.

\section{Conservation in Canada}

by McConkey, O. M., 1952, xix +215 pp., J. M. Dent and Sons (Canada) Ltd., Toronto, $\$ 3.50$.

In a relatively short, well illustrated book, Prof. McConkey of the Ontario Agricultural College, has covered briefly the many aspects of conservation in Canada. In forty-six short chapters dealing with a full range of subjects from Erosion to Education, the primary emphasis is placed on soil conservation and recommended agricultural practices. Brief excursions into such fields as "Forest conservation", "Wildlife", and "Minerals and Oil" are made, but on the whole, foresters will not find too much of interest in this book. The conservation principles to be applied in agriculture are outlined under many headings including: Contour Cultivation, Windbreaks, Irrigation, Pollution, Wind Erosion, Water Erosion, Flood Control, Farm Ponds, Cover Crops, and Crop Rotation, to name a few.

When the author does mention forests and forestry, unfortunately he pictures exploitation and clear cutting as malpractices, and pleas for the rational sustained yield management, complete utilization, and selective cutting he saw in Sweden and Germany, to be applied to Canada's forests. Although some figures are quoted to show the value of the forest products industries, the fact is not brought out that this value is obtained only through exploitation, which is the successful application of industry on any object. Canada's favourable balance of trade and her production of three in every five newspaper pages in the world have resulted from the successful application of industry on the forest resource. It is also unfortunate that a writer on conservation should set up selective cutting as a panacea, in a country where clear cutting will be applied as a silvicultural tool in most forest regions for many years to come, and where a form of selective cutting, or the periodic return to forest stands has resulted in a deteriorated growing stock now evidenced in some forest regions.

Some of the points made in the sections dealing with the forest resource are well founded; one cannot deny the need for rational sustained yield manage- 
ment and better utilization. At times, however, this reviewer wondered if conservation actually conveyed the meaning "preservation" rather than "wise use" of the natural resources.

Conservation in Canada is well written in a clear concise style, with good illustrative material well presented. It is a book concerned primarily with soil conservation in the agricultural regions of Canada.

\section{J. WALTER Giles.}

\section{Forest Entomology}

by S. A. Grabam. 1952 edition, 351 Pp., McGraw Hill Book Co., Inc., Toronto. $\$ 7.50$.

This fundamental book on forest entomology is now in its third edition. The previous ones appeared in 1929 and 1939. As in the other editions, the subject of forest entomology is approached through a consideration of general underlying principles, supplemented by studies of certain insect species, each carefully selected to illustrate how these principles apply in individual instances. The author presents the subject of forest entomology from the viewpoint of forestry, with emphasis placed on the influences of the insects on the forest, rather than on the insects themselves. An ecological, rather than a taxonomic arrangement of species is used.

Owing to the great advances that have been made in the field of forest entomology in the past few years, this second revision is virtually a new book. Some sections have been completely rewritten; a new chapter on detection and appraisal has been incorporated; the chapter dealing with insecticides and their effects has been enlarged, especially with respect to the recent advances in aerial spraying. In the chapters concerned with "Indirect Control", mention is made for the first time of the role played by bacterial, fungi and virus diseases, and the section dealing with predators is greatly enlarged.

The present edition has only one-half the amount of illustrative material compared with the previous one. Much of this is new and superior, although even better material might have been used in some instances. The list of references is enlarged and brought well up to date, not only by the inclusion of references that cover the newer aspects of forest entomology, but also by an adequate treatment of the newer literature on such old established aspects as ecology.

The remarks of the author in the preface to the second edition, that the principles set forth in this book should be of interest not only to students and teachers of forest entomology, but also to economic entomologists, ecologists, foresters, and many others engaged in growing or utilizing forest products, seem to be particularly pertinent in the case of this most recent edition.

J. R. BLAIS.

Logging Mechanization in the USSR

by Koroleff, A., 1952, 158 pp., 46 illustrations, Pulp \& Paper Research Institute of Canada, Montreal, $\$ 5.00$.

This new volume of A Koroleff's is based upon data derived from about one hundred articles from Russian sources which have been published in the 
past five years. New methods and unusual equipment, by our standards, are described in considerable detail.

While the new equipment and methods described are of considerable interest to all who are concerned with logging, what has impressed the reviewer most is the present level of development (technically) of logging in the USSR. It has evolved in a different economy from ours, but from a similar starting point, namely manual logging with the use of horses. It will be readily apparent to the critical reader that many of the techniques and some of the equipment would not be practical under our present economy, whereas they are tailor made for the conditions in USSR. At the same time their approach to the relationship between forestry and logging appears to be universally sound.

Many of the items in this volume will be found intriguing. If they give rise to thought and action that advances our logging techniques, its publication will be well justified. As Koroleff states in his preface, dissemination of knowledge of logging methods and equipment has been entirely one way, from North America to Russia. This is the first time that knowledge of Russian developments in this field have been made available in detail to loggers in North America.

Portable electric stations, powered by efficient producer gas units are used to operate electric power saws, electric powered winches, and electric powered tractors. Considerable attention has been paid to job layout as affected by the prevailing forestry practices. One technique, described in some detail sounds interesting. This is the skidding by yarder and tractor and the hauling on trucks and logging rail cars of whole trees. The trees are limbed at a concentration point by mechanical equipment. The slash is in some cases utilized in the gas producer units to generate power. This technique may find a place on our logging operations if the present work on the extraction of essential oils from coniferous foliage proves economically possible. With regard to water transport, a novel idea propounded is the storage of water in branch streams in the form of solid ice. The idea here is that the rate of runoff will be slowed down and water normally wasted at peak spring runoff can be utilized.

Besides equipment and method, considerable stress is laid on the part labour plays in logging. Considerable effort is being expended to deseasonalize the logging cycle and to promote stability of employment. Incentive systems of payment are described.

'This is an important book because of the insight it gives into the USSR's developments in the field of logging and because of the stimulation that the description of new methods and equipment should bring to our own logging industry.

\section{R. Silversides.}

The Way to Game Abundance, by Grange, W. B., 1949, xviii + 365 pp., Chas. Scribners' Sons, New York, $\$ 6.00$.

While this book is not hot off the presses, it never will be outdated. Foresters and Wildlifers will find its contents stimulating as long as knowledge 
of forest succession is a requisite for managing forest lands. Here is a most readable account of plant successions in Wisconsin and of the animal successions that follow them. Its major thesis is that the only sure way to game abundance is through providing game with appropriate stages of plant succession.

To Mr. Grange, the forest is a complex, dynamic community composed of many forms of life. Within this complex community, there are laws governing changes through time which apply equally to Wisconsin jack pine barrens, to the pine forests of the southeast, or to the mountain valleys of the Columbia Forest. The author has done a good job of presenting sound ecology in popular, readable form.

The remarkable feature of this volume is that it results from a lifetime of observing succession, and of controlling succession for game. The author has shown in practice that what he writes of actually works. He has the axe-handle callouses and the fire blackened boots to prove that his ideas are not armchair theory alone.

Wildlife biologists might wince, however, when the author attempts to explain the cause of the ten year wildlife cycle, perhaps the major Canadian wildlife problem of to-day. With the same confidence that he describes forest succession and varying hare abundance on his own back forty, the author plunges without hesitation into a long, completely undocumented account of what, in his opinion, causes this cycle throughout the Boreal Forest. With numerous sweeping statements and arguments that would sound convincing if one only knew the facts supporting them, Mr. Grange attempts to show that the cycle is caused by cyclic weather, which causes cyclic fires, which causes cyclic successional retrogression, which results in cyclic animal populations. His data are far too general to be thoroughly convincing, but his logic does hang together remarkably well. Biologists would be wise to follow some of his trends of thought, digging deeper for precise facts.

In the last quarter of his book the author shifts from theory to practice. Here he discusses the tools, methods and principles of the control of game abundance by man. This is, of course, mainly a treatise upon controlling plant succession. The chapter headings will convey the scope of this account; these, somewhat abbreviated from the actual headings, are Controlled Burning, Forest Cutting, Cultivation and Food Strips, Woodlot Grazing, Aquatic Habitats, Refuges, Restocking, Predator Control and Enforcement. The first of these is of particular interest and is treated at length. Every Forester should read this account of fire and what it can mean to game, especially every Forester who has helped to spread the myth-"Prevent fire and save our game".

Most principles presented in this book are not new. What the author does is to present them in a fresh new light. Further, forest succession control and game abundance through proper habitat have a habit of remaining in the textbook. Mr. Grange has put them to work on the land.

There is no one with a desire to know more about forest lands who will not benefit from these pages. I especially recommend this book to anyone interested in animal damage to young forests, to anyone interested in fire on wild land, to anyone interested in forest succession, and above all, to anyone interested in our forests as dynamic communities.

R. Y. EDWARDS. 